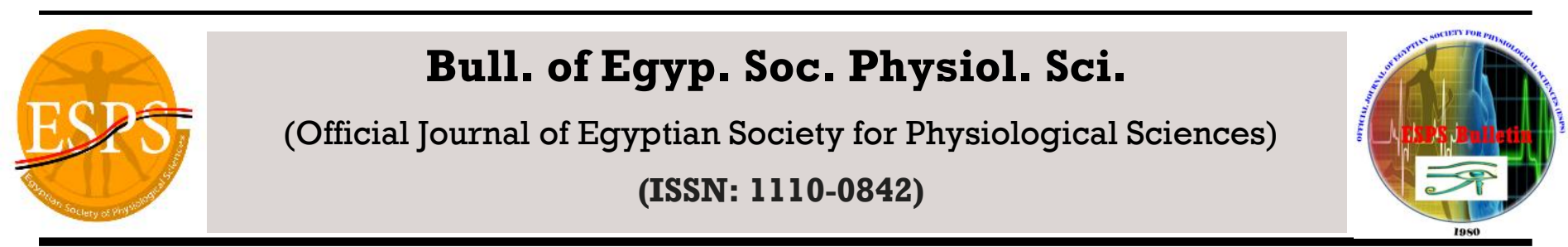

\title{
Effect of Erythropoietin on Unilateral Testicular Ischemia/Reperfusion Injury After Torsion/Detorsion in Rats
}

\author{
Nahid M. Tahoon ${ }^{1}$, Risk M. Elkholy ${ }^{1}$, Sahar A. Elsawy ${ }^{1} \&$ Eman H. Basha ${ }^{1}$ \\ Department of Physiology ${ }^{1}$. Faculty of medicine, Tanta University, Tanta, El Gharbia, Egypt
}

Received: Jul $6^{\text {th }} 2014$

Accepted: Oct $10^{\text {th }} 2014$

Available online: 1 Jan 2015

\section{Keywords}

- erythropoietin,

- ischemia/reperfusion,

- torsion/detorsion,

- Testis.

\begin{abstract}
Background: Testicular torsion is a medical emergency that requires urgent surgical intervention. Aim: To study the effect of erythropoietin (EPO) on unilateral testicular ischemia/reperfusion (I/R) in rats.Methods: 32 adult male wistar rats were divided into 4 equal groups; sham-operated group, 2 hours torsion group, untreated torsion/detorsion (T/D) group and EPO-treated T/D group. In all groups testicular malondialdehyde (MDA), catalase activity, nitrite/ nitrate and tumor necrosis factor-alpha (TNF- $\alpha$ ) were measured in testicular tissue. Free testosterone was measured in serum. Caspase-3 was examined by immunohistochemistry. Histopathological examination of testicular tissue was also done for all groups.Results: At the end of the experimental period, the 2 hours torsion and untreated T/D groups showed significant increases in testicular MDA, nitrite/ nitrate and TNF- $\alpha$ and significant reduction of testicular catalase activity and serum free testosterone. These biochemical results were significantly reversed in EPO-treated T/D group. These results were corroborated by immunohistochemistry of caspase- 3 and histopathological results of testicular tissue in all groups. Conclusion: From these results, it is concluded that, EPO plays an important beneficial role in $I / R$ injury of testis due to its antioxidant, antiinflammatory, antiapoptotic and angiogenic properties and can be used as a novel therapeutic approach in conjunction with surgical repair to decrease the rate of surgical resection of torted testis.
\end{abstract}

Corresponding author: Nahid M. Tahoon, Medical Physiology Department, Faculty of Medicine, Tanta University, Tanta, Egypt. E-mail: nahidtahoon@yahoo.com Tel: 0405672617, Mobile: 01002677609 


\section{INTRODUCTION}

Testicular torsion (TT) is a urological emergency that usually results from rotation of testis round the longitudinal axis of the spermatic cord, frequently seen in newlyborns, children and adolescents. It occurs in approximately one in 4,000 males under 25 years of age with peak age ranging from 7-14 years (1). Many factors are implicated in predisposition of torsion including, inadequate connective tissue within the scrotum and Bell-Clapper deformity with lack of fixation of testis being freely suspended within the tunica viginals. Trauma to the scrotum or strenuous exercise may also initiate TT (2). Rapid diagnosis and immediate surgical treatment are essential to avoid permanent testicular damage. Delay or misdiagnosis more than 6-8 hours and inappropriate treatment usually lead to male infertility due to testicular ischemia, necrosis, infarction and atrophy(3).

Torsion /detorsion (T/D) is a typical condition of ischemia/reperfusion $(I / R)$ in which the tissue damage in the ischemic phase is due to energy deprivation and disruption of cellular homeostasis. The reperfusion phase evokes inflammatory reaction involving reactive oxygen species (ROS), endothelial cells and leukocytes that may aggravate the local injury (4).

Erythropoietin (EPO) is a glycoprotein hormone produced primarily from peritubular fibroblasts of renal cortex in response to hypoxia. Its primary role is to stimulate erythroid progenitor cells (EPC) survival, proliferation and differentiation. Hence, it is commonly used to treat anemia (5). However erythropoietin receptors (EPOR) are detected in erythroid and nonerythroid cells indicating that EPO has biological functions other than erythropoiesis. EPO mRNA is also detectable in brain, liver, spleen, lung and testis but these organs can't substitute for renal EPO in chronic kidney disease (6). EPO is an essential growth factor in hemopoietic tissue. In non hemopoietic tissues, it inhibits apoptosis, stimulates angiogenesis and increases cell proliferation. These effects of EPO are mediated through interactions with EPOR (7). Many animal studies have shown the protective role of EPO against I/R injuries in various organs. However, there are not enough studies which have been conducted on testis especially in humans. Previous studies did not focus on the role of medical treatment besides surgical repair (8). The aim of this study was to evaluate the role EPO on unilateral testicular I/R injury in rats.

\section{MATERIALS AND METHODS}

The present work was carried out on 32 male adult wistar rats of local strain weighing $200 \pm 30$ gm from the animal house of Faculty of Science, Tanta University. All procedures were accepted by ethical committee of Tanta University (code number: 13/06/1938). Rats were housed in isolated cages in temperature controlled animal room, on 12 hour light/ dark cycle with free access to water and food adlibitium. These animals were divided into 4 equal groups; each of 8 rats.

\section{I/R of testis:}

Under complete aseptic conditions ( Chlorhexidine and $70 \%$ alcohol as a surface disinfictant to work area and one intraperitoneal injection of $50 \mathrm{mg} / \mathrm{kg}$ b.w. ceftriaxone was performed in all rats), rats were anaesthetized with i.p. injection of pentobarbital $\quad(50 \quad \mathrm{mg} / \mathrm{kg}), \quad$ a midline 
abdominoscrotal incision (because of wide inguinal canal, the testes move freely between abdomen and scrotum). In the sham-operated group, the left testis was delivered and relocated into the scrotum with orchiopexy (fixing testis to scrotum by a $6 / 0$ silk suture). In torted groups, testicular torsion was done by rotating the left testis 2 times (based on other studies) around the longitudinal axis of the spermatic cord $\left(720^{\circ}\right)$ in a clock wise direction and torsion was maintained by orchiopexy for 2 hours (ischemic phase) and the incision was closed. In T/D group, after 2 hours of torsion, left testis was detorted 2 times $\left(720^{\circ}\right)$ in an anticlockwise direction after cutting the fixation suture. These T/D animals were allowed to live for 4 hours (reperfusion phase) after closing the incision before sample collection (9).

\section{Experimental groups:}

Group I: Sham-operated: Were injected with a single dose of $1.0 \mathrm{ml}$ normal saline i.p.

Group II: 2 hours torsion: Were injected with single dose of $1.0 \mathrm{ml}$ normal saline i.p.

Group III: Untreated T/D: Were injected with a single dose of $1.0 \mathrm{ml}$ normal saline i.p. $1 / 2$ an hour before detorsion

Group IV: EPO-treated T/D: Were injected with a single dose of EPO (Egyptian Company of Biotech Industries) $3000 \mathrm{IU} / \mathrm{Kg} 1 / 2$ an hour before detorsion (10).

\section{Sample collection:}

At the end of the experiments, rats were anaesthetized, blood samples were collected by decapitation, serum was separated by centrifugation at $3000 \mathrm{rpm}$ for $10 \mathrm{~min}$ and kept in clean storage aliquots. Left testes were carefully dissected, frozen and cut transversely into 2 halves; one half was weighed and kept at $-80^{\circ} \mathrm{C}$ for tissue biochemical assay; and the other half was preserved in Bouin's fixative for 6 hours and subsequently washed and stored in 50\% ethyl alcohol and embedded in paraffin for histological and immunohistochemical examination.

\section{Tissue homogenate:}

Tissue was perfused with phosphate buffered saline solution at $\mathrm{pH} 7.5$ containing 0.16 heparin to remove red blood cells and clots. Tissue was homogenized in 5-10 $\mathrm{ml}$ cold buffer $(50 \mathrm{mM}$ potassium phosphate, $\mathrm{pH}$ 7.5) per gram tissue in the homogenizer. The homogenate was centrifuged at 4000r.p.m for 15 minutes at $4^{\circ} \mathrm{C}$. The supernatant was stored at $-80^{\circ} \mathrm{C}$ for assay (9).

\section{Methods:}

Testicular malondialdehyde (MDA): was measured by colorimetric method of Ohkawa et al.(11).

Testicular catalase activity: was measured by colorimetric method of Aebi.(12).

Testicular total nitrite/nitrate: was measured by colorimetric method of Montgomery and Dymock.(13).

Testicular tumor necrosis factor alpha (TNF- $\alpha$ ): was measured by commercial sandwich ELISA kit according to the manufacturer's instructions (Biosource, international, Camarillo, California, USA). Sensitivity is $15 \mathrm{pg} / \mathrm{ml}$. Intra-Assay: CV $<10 \%$ and Inter-Assay: CV $<12 \%$ (14) .

Serum free testosterone: was measured by commercial ELISA kit Bio Check, Inc. 323 Vintage Park Dr .Foster City, CA 94404. Catalog No. : BC- 1115 . Sensitivity is $0.05 \mathrm{ng} / \mathrm{ml}$. IntraAssay: CV <6.4\% and Inter-Assay: CV $<4.4 \%$ (15). 
Immunohistochemical determination of caspase3 activity:

By incubation of sections of left testes with monoclonal antibodies against caspase-3 according to the method described by (16). Results were scored semiquantitatively as each section was carefully examined under high power of light microscope for nuclear immunostaining of apoptotic cells (brown colored) and categorized according to the percentage ratio of immunostained nuclei to total nuclei in the field as follows: Score 1: no nuclear staining (negative).

Score 2: $1-9 \%$ of cells positive for caspase-3.

Score 3: $>10 \%$ of cells positive for caspase-3.

Histopatholgoical examination: Was done following standard techniques of hematoxylin and eosin ( H \& E) staining (17).

\section{Statistical analysis:}

All values were expressed as mean $\pm \mathrm{SD}$. Data were statistically analyzed using one way ANOVA for multiple group comparisons, followed by Scheffe $(\mathrm{F})$ test for comparison between individual groups. Significance was set at $(\mathrm{P} \leq 0.05)$. Pearson correlation coefficient was determined using SPSS computer program version 17 (18).

\section{Linear Correlation Coefficient [r]:}

$$
r=\frac{\Sigma(\mathrm{X}-\overline{\mathrm{X}})(\mathrm{y}-\overline{\mathrm{y}})}{\sqrt{\{\Sigma(\mathrm{X}-\overline{\mathrm{x}}) 2\}}\{\Sigma(\mathrm{y}-\overline{\mathrm{y}}) 2\}}
$$

Where :

$\mathrm{X}=$ Independent variable.

$\mathrm{Y}=$ Dependent variable
All animals survived till the end of experimental period.

\section{As shown in Table (1\&2) and Fig. (1):}

The 2 hours torsion group as well as the untreated T/D group produced a significant increase in testicular MDA, nitrite/nitrate and TNF- $\alpha$ and significant decrease of testicular catalase activity and serum free testosterone when compared with sham-operated group $(\mathrm{P}=0.01)$. $\mathrm{By}$ immunohistochemistry, both groups induced more than $10 \%$ of apoptotic cells positive for caspase-3 when compared with the sham-operated group as shown in Fig. (1a-c).

However, all changes produced by untreated T/D group were statistically insignificant when compared with 2 hours torsion group $(\mathrm{P}=0.069)$.

The results showed that EPO-treated T/D group produced statistically significant improvement in all measured parameters when compared with untreated T/D group $(\mathrm{P}=0.01)$; EPO produced significant decrease of testicular MDA, nitrite/nitrate and TNF- $\alpha$ and significant increase of testicular catalase activity and serum free testosterone. Immunohistochemistry showed a significant reduction in number of apoptotic cells positive for caspase- 3 to less than $10 \%$ (score-2) as shown in fig. (1d).

Significant negative correlation was found between serum free testosterone level and either testicular MDA, nitrite/nitrate or TNF- $\alpha$ and significant positive correlation with catalase activity $(\mathrm{P}=0.001)$ as shown in table (2).

Histopathological results confirmed biochemical and immunohistochemical results as shown in fig (2a-d).

\section{RESULTS}


Tahoon et al.,

Table (1): Mean \pm SD and statistical significance of testicular MDA, catalase activity, nitrite/nitrate, TNF- $\alpha$ and serum free testosterone among studied groups:

\begin{tabular}{|c|c|c|c|c|}
\hline Parameters & $\begin{array}{l}\text { I: Sham- } \\
\text { operated } \\
(\mathrm{N}=8)\end{array}$ & $\begin{array}{c}\text { II- 2hours } \\
\text { torsion } \\
(\mathrm{N}=8)\end{array}$ & $\begin{array}{c}\text { III-untreated } \\
\text { T/D } \\
(\mathrm{N}=8)\end{array}$ & $\begin{array}{c}\text { IV-EPO- } \\
\text { treated T/D } \\
(\mathrm{N}=8)\end{array}$ \\
\hline $\begin{array}{l}\text { MDA } \\
(\mathrm{nmol} / \mathrm{g} \text { tissue })\end{array}$ & $1.23 \pm 0.06$ & $1.33 \pm 0.03 *$ & $1.36 \pm 0.03 *$ & $1.25 \pm 0.06 \#$ \\
\hline $\begin{array}{l}\text { Catalase activity } \\
\text { (U/g tissue) }\end{array}$ & $0.193 \pm 0.005$ & $0.184 \pm 0.004 *$ & $0.181 \pm 0.004^{*}$ & $0.193 \pm 0.005 \#$ \\
\hline $\begin{array}{l}\text { Nitrite/nitrate } \\
(\mu \mathrm{mol} / \mathrm{g} \text { tissue })\end{array}$ & $20.35 \pm 0.54$ & $26.24 \pm 0.38 *$ & $26.46 \pm 0.40 *$ & $20.34 \pm 0.49 \#$ \\
\hline $\begin{array}{l}\text { TNF- } \alpha \\
\mathrm{pg} / \mathrm{g} \text { tissue }\end{array}$ & $26.23 \pm 5.30$ & $97.38 \pm 6.41 *$ & $100.50 \pm 6.20 *$ & $62.56 \pm 6.19 \#$ \\
\hline $\begin{array}{l}\text { Serum free } \\
\text { Testosterone }(\mathrm{ng} / \mathrm{ml})\end{array}$ & $5.30 \pm 1.69$ & $3.00 \pm 1.26 *$ & $2.60 \pm 0.97 *$ & $5.00 \pm 1.30$ \\
\hline
\end{tabular}

F-value=15.03 for MDA, 17.82 for catalase activity, 12.35 for nitrite/nitrate, 186.61 for TNF- $\alpha$ and 8.25 for serum free testosterone.* Denotes statistical significance of group II and III versus group I at $\mathrm{P}=0.01$ \# Denotes statistical significance of group IV versus group III at $\mathrm{P}=0.01$.

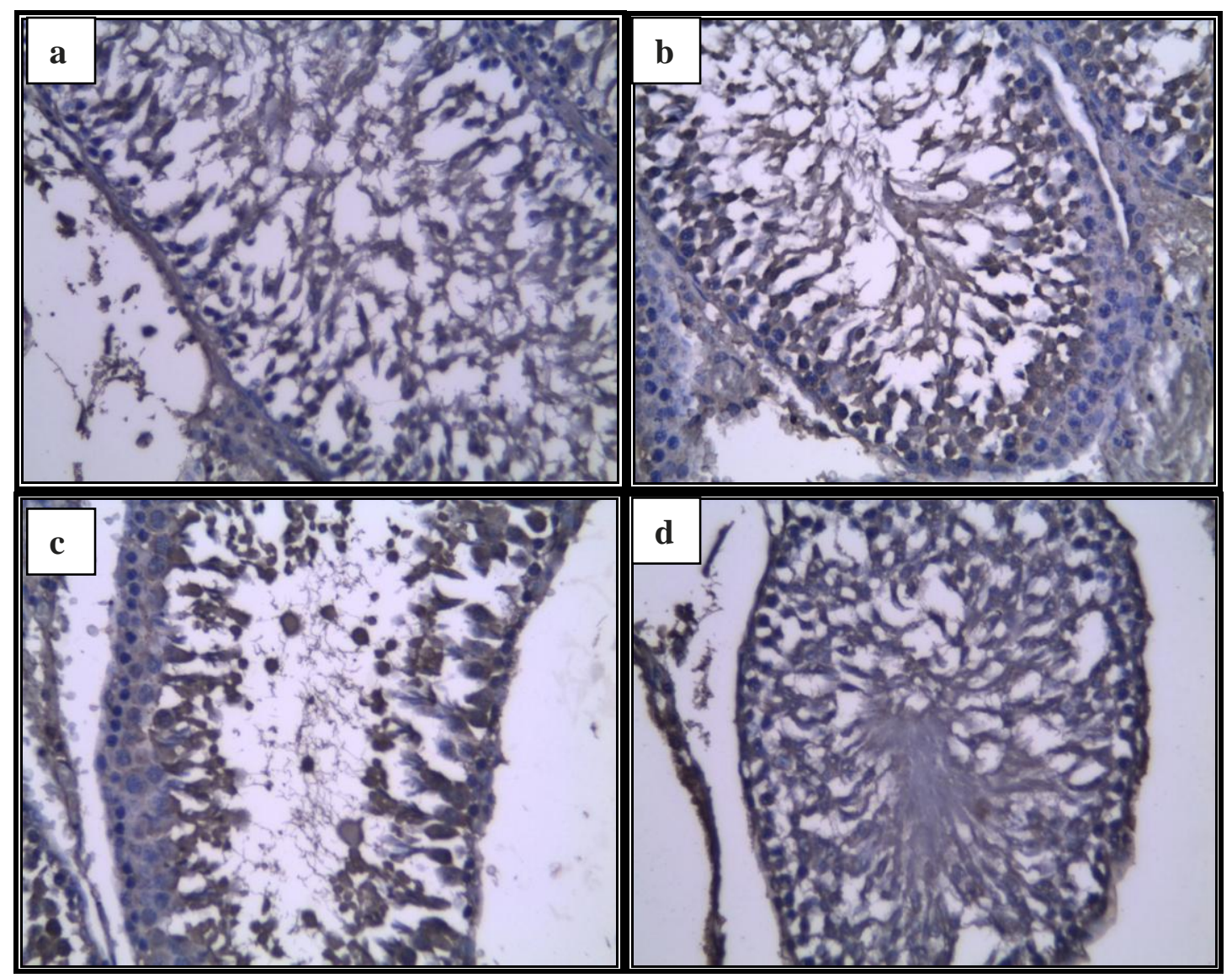

Fig. (1): Immunoreactivity of testicular section of a) sham-operated group showing negative for caspase-3 (score-1: no apoptotic cells), .b) 2 hours torsion group showing $>10 \%$ of cells positive for caspase-3, c) untreated T/D group showing $>10 \%$ of cells positive for caspase-3 (score-3) and d) EPO-treated T/D group showing <10\% of cells positive for caspase-3 ( Pap stain $\mathrm{x} 400$ ). 

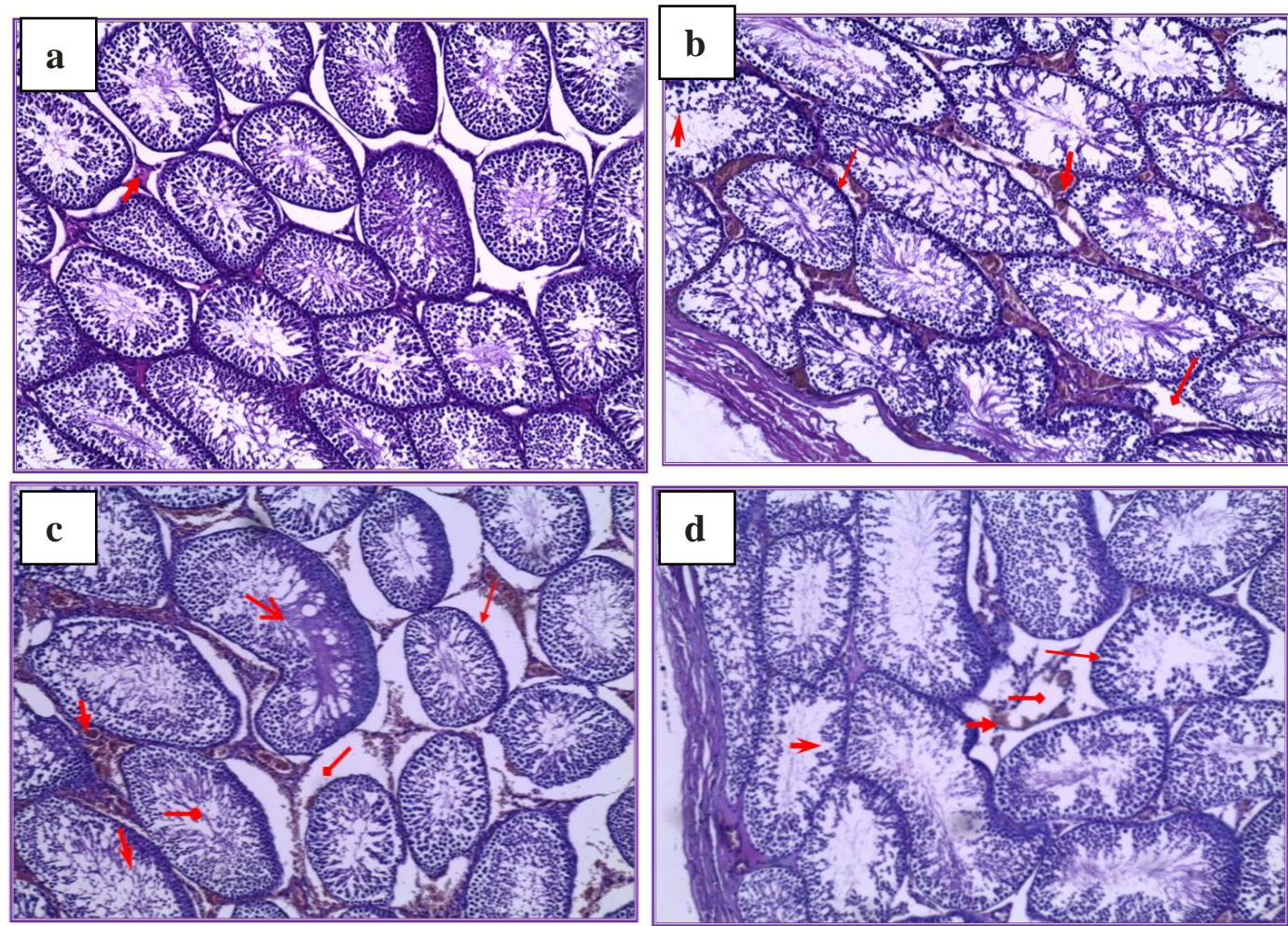

Fig. (2): H\&E staining of testicular section of a) sham-operated group showing normal testicular architecture and slightly congested vessels, b) 2 hours torsion group showing marked congested interstitial vessels ( ), mild edema ( ), thick basement membrane (BM) ( ) and loss of cohesions of spermatogenic cells ( ),c) untreated T/D group showing severe congestion ( ), severe edema ( ), thick basement membrane (BM) ( ) with focal loss of cohesions of spermatogenic cells ( ), sequestrated spermatogenic cells in the lumen ( ) and hyalinization ( ) and d) EPO-treated T/D group showing mild congestion of interstitial vessels ( ), minimal edema (__ mild thickening of basement membrane (BM) ( ) and mild loss of cohesions of spermatogenic cells ( _ (4E x 125).

Table (2): Correlation between serum free testosterone and either testicular MDA, catalase activity, nitrite/nitrate or TNF- $\alpha$ in Sham-operated, the 2 hours torsion, Untreated T/D and EPO-treated T/D groups

\begin{tabular}{|l|c|c|}
\hline \multirow{2}{*}{} & \multicolumn{2}{|c|}{ Serum free testosterone $(\mathrm{ng} / \mathrm{ml})$} \\
\cline { 2 - 3 } & r-value & p-value \\
\hline MDA $(\mathrm{nmol} / \mathrm{g}$ tissue) & -0.591 & $\mathbf{0 . 0 0 1} *$ \\
\hline Catalase activity $(\mathrm{U} / \mathrm{g}$ tissue $)$ & 0.651 & $\mathbf{0 . 0 0 1}$ \\
\hline Nitrite $/$ nitrate $(\mu \mathrm{mol} / \mathrm{g}$ tissue) & -0.684 & $\mathbf{0 . 0 0 1}$ \\
\hline TNF- $\boldsymbol{\alpha}(\mathrm{pgm} / \mathrm{g}$ tissue) & -0.596 & $\mathbf{0 . 0 0 1}$ \\
\hline
\end{tabular}

$\mathrm{P}$-values written in bold are statistically significant

\section{DISCUSSION:}

Torsion/detorsion

(T/D) like

ischemia/reperfusion $(\mathrm{I} / \mathrm{R})$ is a biphasic process that produces cell damage either during ischemia due to energy deprivation with subsequent disruption of cellular homeostasis, or during the reperfusion phase secondary to a wide and complex array of inflammatory responses involving ROS, endothelial cells and leukocytes 
that may aggravate the local injury and impair remote organ function (19).

The significant increase in oxidative stress (increased MDA and decreased catalytic activity) in the 2 hours torsion and Untreated T/D groups could be due to the prolonged ischemia which leads to oxidation of ATP with production of hypoxanthine as a breakdown product. This oxidation results in molecular oxygen being converted into highly reactive superoxide and hydroxyl radicals. On reperfusion, oxygen needed for conversion of hypoxanthine to uric acid becomes available resulting in generation of an enormous amount of free radicals which causes lipid peroxidation in the cell and mitochondrial membranes leading to disruption of cellular integrity (20). Sperms are highly sensitive to lipid peroxidation due to their high content of polyunsaturated fatty acids in their plasma membranes (21). Oxidative damage occurs when the endogenous stores of antioxidant enzymes become unable to cope with the flood of free radicals generated after $\mathrm{I} / \mathrm{R}$ resulting in damage of sperm membranes, proteins and DNA (22).

Under conditions of ischemia, conversion of NO to nitrite may be catalyzed by deoxyhemoglobin, deoxymyoglobin, components of mitochondrial electron transport chain (23) and enzymatic reduction by xanthine oxidoreductase (24). Also, the increase in cytokine production like TNF- $\alpha$ during hypoxic and inflammatory condition may be responsible for the increased NO production. Many cells such as endothelial cells, phagocytic cells and sertoli cells are capable of NO release (25). NO can easily react with superoxide ion to produce the very harmful substance proxynitrite which can react with enzymes, thiol esters and glutathione (26). Nitrating agents may have strong inhibitory potential on the spermatozoal mitochondrial functions (27). Also, NO especially via inducible nitric oxide synthase (iNOS), can activate many inducible intracellular pathways like NFk-B which may lead to cellular apoptosis (28).

The 2 hours torsion and the Untreated T/D groups induced more than $10 \%$ of apoptotic cells positive for caspase-3 (score-3) when compared with the sham-operated group. Apoptosis is crucially dependant on the activation of certain intracellular proteases, called caspases, typically activated in a cascade fashion (29). Hadi et al. (2014) proved the onset of apoptotic program shortly after the onset of ischemia but the process is amplified during reperfusion (30). The activation of caspases may be due to replenishment of high-energy phosphates together with ROS generation and calcium overload in the cytoplasm and mitochondrial matrix leading to release of cytochrome $\mathrm{C}$ and activation of caspase-9 (initiator) until reaching caspase-3 (terminator) implicated in the last step of apoptosis (31). Hyman and Yuan. (2012) proved that the increase in caspase-3 during ischemia is responsible for tissue damage and that selective caspase-3 inhibitor affords protection of tissues against ischemic insult (32).

The significant decrease in free serum testosterone that occurred after 2 hours torsion and Untreated T/D groups may be due to loss of steroidogenesis capacity of leydig cells which suffer from oxidative stress during reperfusion leading to lipid peroxidation, protein denaturation and DNA damage. Multiple apoptotic figures affecting the interstitial cells of Leydig as shown by immunohistochemical staining of caspase-3. 
They may also suffer from apoptosis prior to germ cells (33).

The EPO-treated T/D group showed significant reversal of all measured biochemical parameters in comparison to the untreated T/D group. Immunohistochemistry showed regression of apoptotic cells to (score-2) and histopathological results showed improvement in the form of mild congestion, minimal edema and mild loss of cohesion of spermatogenic cells.

The antioxidant effect EPO (decreased MDA and increased catalytic activity) can be explained by direct effect by induction of hemeoxygenase-1 enzyme (via PI3K/Akt pathway). The latter catalyzes heme degradation into carbon monoxide, iron and biliverdin (reducing agent) (34). Indirect antioxidative effect of EPO is likely due to increase in young erythrocytes which are rich in antioxidant enzymes. Enhanced erythropoiesis also induces iron depletion and thereby inhibiting irondependant oxidative injury (35).

The decrease in NO production by EPO may be due to its ability to increase ionic calcium which suppresses L-arginine-NO pathway and NOS expression (36). However, other studies reported that EPO increases NO production (37).

The antiinflammatory effect of EPO may be through its action on mature immune cells such as macrophages and antigen-stimulated T-cells. EPO also can increase expression of the protective cytokine IL-10 which has an inhibitory effect on TNF- $\alpha$, IL -1 and IL-6 (38).

The antiapoptotic effect of EPO could be explained by its ability to increase expression of B-cell lymphoma leukemia gene 2 (Bcl-2), an antiapoptotic protein that prevents mitochondrial depolarization and the molecular chaperone heat shock protein 70 (HSP-70) in I/R models (39). EPO directly protects cells by activating EPO receptor/ Janus type protein tyrosine kinase family (JAK-2 kinase) leading to activation of PI3K/Akt pathway, upregulation of B-cell lymphoma leukemia extra large (Bcl-XL) and preventing activation of caspase-3, 8,9 and DNA fragmentation (39).

EPO possesses angiogenic effects through formation of new blood vessels either from endothelial progenitor cells (EPC) or by sprouting from preexisting vessels (5). It induces EPC proliferation and migration, increases expression of endothelial growth factor, improves microvascularization and decreases interstitial cell fibrosis (40).

Serum free testosterone showed a significant increase after EPO. This may be due to the direct stimulating effect of EPO on Leydig cells through protein kinase $\mathrm{C}(\mathrm{Akt})$ dependant pathway (41). Yamazaki et al. (2004) also considering EPO as one of the growth factors of Leydig cells besides its direct stimulation of germ cells proliferation (42). Vasoproliferative and neoangiogenic ability of EPO stimulates Leydig cells in both testes to produce testosterone (43).

\section{CONCLUSION \& RECOMMENDATION:}

It is concluded that, EPO treatment can be used as a novel therapeutic approach in T/D of testis in conjunction with surgical repair due to its antioxidant, antiinflammatory, antiapoptotic and angiogenic properties to ameliorate the injurious effect of $I / R$ and to decrease the rate of surgical resection of the torted testis. However, we recommend additional basic research in different 
species, especially human beings.

\section{ACKNOWLEDGEMENT:}

Great thanks for Dr/ Karima Ibraheme ElDesuky, professor of histopathology for her help

\section{REFERENCES}

1. Zhao LC, Lautz TB, Meeks JJ, and Maizels

M.: Pediatric testicular torsion epidemiology using a national database: incidence, risk of orchiectomy and possible measures toward improving the quality of care. J Urol; 186: 9-13, (2011).

2. Farrington NL, Lucky MA, Barnes $T$ and Calvert R.: Confirmed testicular torsion in a 67 years old. J Surg Case Rep; 1: 1-2, (2014).

3. Shimizu S, Martin DT, Dimitriadis F, Satoh K and Saito M.: The effect of ischemic preconditioning and postconditioning on testicular torsion-detorsion injury. Global $\mathrm{J}$ Biochem; 1-16, (2012).

4. Liang T, Metcalfe P, Sevcik W and Noga M.: Retrospective review of diagnosis and treatment in children presenting to the pediatric department with acute scrotum. Am J Roent; 200(5):444-449, (2013).

5. Ahn S, Min SK, Min S, Suh JH, Kim SJ and Ha J.: Early sustained injections of erythropoietin improve angiogenesis and restoration of perfusion in the ischemic mouse hindlimb. J Korean Med Sci; 27 (9):1073-1078, (2012).

6. Youssoufian H, Longmore G, Neumann D, Yoshimura A and Lodish HF.: Structure, function, and activation of the erythropoietin receptor. Blood; 81(9): 223236, (2013).
7. Morais C, Johnson DW, Vesey DA, Gobe GC.: Functional significance of erythropoietin in renal cell carcinoma. BMC Cancer; 10: 1314, (2013).

8. Ergur BU, Kiray M, Pekcetin C, Bagriyanik HA and Erbil G.: Protective effect of erythropoietin pretreatment in testicular ischemia reperfusion injury in rats. J Pediatr Surg; 43(4): 722-728, (2008).

9. Aktas A, Tuncer MC, Yuldirım A, Nergiz, Y and Akkus M.: Protective Effects of Melatonin on Testicular Torsion and Detorsion Damage in Sprague-Dawley Rats. Int $\mathrm{J}$ Morphol; 29 (1): 7-15, (2011).

10. Manizheh SM, Maryamalsadat KS, Jafar SR, Reza RM, Leila $R$ and Nadereh $R$, et al.: The Ovario-Protective Effect of Erythropoietin against Oxidative Damage Associated with Reperfusion Following Ovarian Torsion in Rat. Am $\mathbf{J}$ of Anim and Vet Sci; 6 (1): 18-24, (2011).

11. Ohkawa H, Ohishi N and Yagi K.: Assay for lipid peroxides in animal tissues by thiobarbituric acid reaction. Anal Biochem; 95: 351-358, (1979).

12. Aebi H.: Catalase in vitro. Methods Enzymol; 105: 121 - 126, (1984).

13. Montgomery HAC and Dymock JF.: Colorimetric determination of nitric oxide. In Analyst; 86: 414, (1961).

14. Rajadura M.: Comparative effect of aegle marmelos extract and alpha tocopherol on serum lipids, lipid peroxidation and cardiac enzymes in rats with isoproterenol-induced myocardial infarction. Sin Med J.; 46(2): 78-81, (2005). 
15. Tietz $N W$.: Clinical guide to laboratory tests. W B Saunders, Co., Philadelphia; $3^{\text {rd }}$ edition: pp. 578- 580, (1995).

16. Kim SK, Yoon YD, Park YS, Seo JT and Kim JH.: Involvement of the Fas-Fas ligand system and active caspase- 3 in abnormal apoptosis in human testes with maturation arrest and Sertoli cell-only syndrome. Fertil Steril; 87 (3): 547-553, (2007).

17. Hammersen F.: Histology, color atlas of microscopic anatomy 3rd and end. Edition. P: 356, (1985).

18. Indrayan A and Sarmukaddam SB: Medical Biostatics $1^{\text {st }}$ Ed. Marcel-Dekker, Delhi, India. Pp:43-59, (2001).

\section{Raju AB, Challa SR, Akula A, Kiran A} and Harinadh GB.: Evaluation of oxidants and antioxidants balance in experimentally induced testicular injury by ischemia reperfusion in rats. Eur $\mathbf{J}$ Gen Med; 8(2):117-121, (2011).

20. Hamidian Jahromi A, Kessaris N, Sharifian $M$ and Roozbeh J.: Protective effect of pentoxifylline in the kidney perfusion fluid on the transplanted kidney. Saudi J Kidney Dis Transpl; 20 (2): 290-291, (2009).

21. Henkel R.: The impact of oxidants on sperm function. Andrologia; 37 (6): 205-206, (2005).

22. Halliwell B.: Free radicals and antioxidants updating a personal view. Nutr Rev; 70(5): 257-265, (2012).

23. Gautier C, van Faassen E, Mikula I, Martasek P and Slama-Schwok A.: Endothelial nitric oxide synthase reduces nitrite anions to NO under anoxia. Biochem
Biophys Res Commun; 341 (3): 816-821, (2006).

24. Huang KT, Keszler A, Patel N, Patel RP, Gladwin MT, Kim-Shapiro DB, et al.: The reaction between nitrite and deoxyhemoglobin. Reassessment of reaction kinetics and stoichiometry. J Biol Chem; 280 (35):31126-31131, (2005).

25. Filho DW, Torres MA, Bordin AL, Crezcynski-Pasa TB and Boveris A.: Spermatic cord torsion, reactive oxygen and nitrogen species and ischemic reperfusion injury. Mol Aspects Med; 25 (2): 199-210, (2004).

26. Ozokutan BH, Kucukaydin M, Muhtaroglu S and Tekin Y.: The role of nitric oxide in testicular ischemia-reperfusion injury. J Pediatr Surg; 35(1):101-103, (2000).

27. Vera Y, Erkkila K, Wang C, Nunez C, Kyttanen S, Lue Y, et al.: Involvement of p38 mitogen-activated protein kinase and inducible nitric oxide synthase in apoptotic signaling of murine and human male germ cells after hormone deprivation. Mol Endocrinol; 20 (7): 597-609, (2006).

28. Basar MM, Kisa U, Tuglu D, Yilmaz E, Basar $\boldsymbol{H}$ and Caglayan O.: Testicular nitric oxide and thiobarbituric acid reactive substances levels in obstructive azoospermia: a possible role in pathophysiology of infertility. Mediators Inflamm; 3:1-5, (2006).

29. Gry DC, Mahrus $S$ and Wells JA.: Activation of specific apoptotic caspases with an engineered small molecules activated protease. Cell; 142(4): 637-646, (2010). 
30. Hadi NR, Yusif FG, Yousif $M$ and Jaen

KK.: Both castration and goserelin acetate ameliorate myocardial ischemia reperfusion injury and apoptosis in male rats. ISRN Pharmacol; (2014): 1-7, (2014).

31. Kirkland RA, Windelborn JA, Kasprzak JM and Franklin JL.: Bax-induced pro-oxidant state is critical for cytochrome $\mathrm{C}$ release during programmed neuronal death. J Neurosci; 22 (15): 6480-6490, (2002).

32. Hyman BT and Yuan J.: Apoptotic and non apoptotic roles of caspases in neuronal physiology \& pathophysiology. Nat Rev Neurosci; 13(6): 395-406, (2012).

33. Creasy D, Bube A, Rijk E, Kandori $H$, Kuwahara M, Masson R, et al.: Proliferative and non proliferative lesions of the rat and mouse male reproductive system. Toxicol Pathol; 40(6): 40121, (2012).

\section{Katavetin P, Inagi R, Miyata T, Shao J, Sassa} $\boldsymbol{R}$, Adler $S$, et al.: Erythropoietin induces hemeoxygenase-1 expression and attenuates oxidative stress. Biochem Biophys Res Commun; 359(4):928-934, (2007-b).

35. Katavetin $P$, Tungsanga $K$, Ong $S E$ and Nangaku M.: Antioxidative effects of erythropoietin. Kidney Int Suppl; 107:1015, (2007-a).

36. Akeora B, Altug ME, Kontas T and Atik E.: The protective effect of darbepoietin alpha on experimental testicular torsion and detorsion injury. Int J Urol; 14 (9): 846850, (2007).

37. Bojana B, Cokic VP, Wang L, Piknova B, Teng R, Schechter AN, et al.:
Erythropoietin and hypoxia increase erythropoietin receptor and nitric oxide levels in lung microvascular endothelial cells. J Cytokine; 45(2) :129-135, (2011).

38. Hojman $P$, Taudorf $S$, Lundby $C$ and Pedersen PK.: Erythropoietin augments the cytokine response to acute endotoxininduced inflammation in humans. Cytokine; 45 (3): 154-157, (2009).

39. Yazihan $N$ and Kavas GO.: Protective effect of erythropoietin in renal ischemiareperfusion injury. Open Drug Discov J; 2: 3-7, (2010).

40. Lu J, Yao YY, Dai QM, Ma GS, Zhang

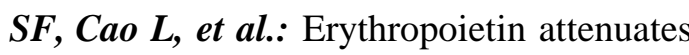
cardiac dysfunction by increasing myocardial angiogenesis and inhibiting interstitial fibrosis in diabetic rats. Cardiovasc Diabetol; 7:100-105, (2012).

41. Buemi M, Vaccaro M, Sturiale A, Galeano MR, Sansotta C, Cavallari $\quad$ V, et al.: Recombinant human erythropoietin influences revascularization and healing in a rat model of random ischemic flaps. Acta Derm Venereol; 82 (6): 411- 417, (2002).

42. Yamazaki T, Kanzaki M, Kamidono $S$ and Fujjsawd M.: Effect of erythropoietin on leydig cell is associated with the activation of stat 5 pathway. Mol Cell Endocrinol; 213 (2): 193-198, (2004).

43. Koseoglu B, Yilmaz E, Ceylan K, Uzun E, Bayram I and Hizli F.: The protective effect of erythropoietin on testicular torsion/detorsion: an experimental study. Int Urol Nephrol; 41 (1): 85-91, (2009). 
تأثير الاريثروبيوتين على التدهور الناتج عن انقاص تدفق الام الموضعى ثم اعادة الاثباع الدموى الناتج عن التواء إحدى الخصيتين ثم ارجاعها فى الفئران البيضاء

نـاهد م. طاحون, رزق م. الخولى, سحر أ. الصاوى و ايمان ه. باشا

$$
\text { قسم الفسيولوجيا الطبية }
$$

كلية الطب. جامعة طنطا. طنطا. الغربية. مصر

الهدف من البحث:در اسة تأثير هرمون الاريثروبيوتين على إنقاص تدفق الدم الموضعى ثم إعادة الإشباع الدموى الناتج عن التواء إحدى الخصيتين ثم ارجاعها فى الفئر ان البيضاء فى الفئر ان البيضاء طريقة البحث: تم إجر اء البحث على 32 فأر اً ذكراً بالغاً تم تقسيمهم إلى 4 مجموعات متساوية : المجموعة الضابطة و مجموعة التو اء الخصية لمدة ساعتين و مجمو عة التو اء الخصية وإرجاعها دون علاج و مجموعة التواء الخصية وإرجاعها المعالجة بالاريثروبيوتين فى نهاية التجربة تم قياس معدل كل من: المالونديالدهيد، إنزيم الكاتالاز، النتريت/ نيترات و عامل تتخرز الأور امـ ألفا فى أنسجة الخصية و هرمون التستوستيرون فى السيرم. كما تم اجر اء در اسة مناعية هستوكيميائية خاصة بالكاسباس- 3 فى نسيج الخصية و فحص هستوباثولوجى لأنسجة الخصية. النتائج: وجد أنه فى حالة التو اء الخصية لمدة ساعتان وفى حالة التو اء الخصية و إرجاعها دون علاج كان هناك زيادة ذات دلالة إحصائية فى مستوى كل من المالونديالدهيد، النتريت/ نيتر ات و عامل تتخرز الأورام - الفا فى أنسجة الخصية كما وجد أن هناك نقص ذو دلالة إحصائية فى مستوى كل من انزيم الكاتالاز فى أنسجة الخصبة وهرمون التستوستيرون فى السيرم بالمقارنة بالمجمو عة الضابطة. أوضحت النتائج المناعية الهستوكيميائية الخاصة بالكاسباس - 3 زيادة عدد موت الخلايا المبرمج الى الدرجة الثالثة فى كلا المجمو عتين مقارنة بالمجمو عة الضابطة كما تم إثبات هذه النتائج بنتائج الدر اسة الهستوباثولوجية. فى حالة التواء الخصية وإرجاعها المعالجة بالاريثروبيوتين فقد انعكست جميع هذه النتائج بشكل ذو دلالة إحصائية على المستوى الكيميائى و المناعى و الهنتوباثولوجى مقارنة بمجمو عة التو اء الخصبة و إرجاعها دون علاج. الاستثتاج و التوصية : ثبت أن الاريثروبيوتين يلعب دوراً مفيداً (مضاد للأكسدة , للالتهاب وللموت المبرمج) فى حالات إنقاص تدفق الدم الموضعى ثم إعادة الإشباع الدموى بإحدى الخصيتين فى الفئران. هذه الدراسة توصى باستخدام هرمون الاريثروبيوتين بجانب العلاج الجر احي لتقليل الضرر الناتج عن إنقاص تدفق الدم الموضعى ثم إعادة الإشباع الدموى وتقليل إز الة الخصية المصابة. لكن هذا يتطلب أبحاثاً إضافية خصوصاً على الانسان. 